\title{
ALEXANDRIA
}

Revista de Educação em Ciência e Tecnologia

\section{EL ASTRONAUTA PREPARA EL DESCENSO}

La enorme luna blanca está tan cerca y aún no puedo creer que soy yo el elegido para dejar mi huella en sus desiertos.

Todo es ya la blancura.

Miro entre olas de sombra a la ballena blanca del cielo.

Hijo de turbias razas que temieron la noche, las ideas oscuras, los dioses, las pieles oscuras, ahora soy el ápice del arpón antiquísimo que codicia la carne de este planeta blanco.

Alguien sabe en lo alto que estoy girando en tomo de la luna. No puedo recordar en este instante si Él habló de la luna en sus parábolas. No sé si aprobará que un hombre hecho de polvo, de polvo y de pecado, pise los peldaños del cielo.

Para saber quién soy, sé que debo contar con la última estrella, sentir que en mí se cruzan infinitas distancias,

que soy el ojo que titila de profundidades incandescentes, la mano que moldea como cera las masas de hierro, la que traza las infimas parábolas y levanta en neblina la geometría de las aguas.

Nunca estuve tan lejos de mí mismo (porque soy el planeta, porque el aire es mi sangre, porque verdes criaturas silenciosas sin cesar se convierten en carne mía porque sangrantes animales sacrificados se convierten sin fin en mi fuerza y en mi pensamiento)

pero sé que no sueño, sé que estoy ascendiendo a otro tiempo.

Vengo aquí a visitar los reinos de mi infancia, un país de espectrales cañones de polvo, un país de nostálgicos cráteres como lagunas secas, 
un país de opresivo y submarino silencio.

Sé que esta soledad tiene su precio,

pues todo explorador de jamás visitados abismos

algo profana con su carne mortal,

algo perturba con su mente atestada de recuerdos.

Qué pensará este ser de imposible blancura

cuando sienta en sus valles el peso de un ser vivo?

Nunca nadie tocó sus plateadas polvaredas inmóviles,

nunca el dolor humano ni la esperanza humana agitaron su atmósfera,

nunca sintió su piedra eterna la tremolación de la vida.

Si se soltara una paloma a volar

como flecha en este espacio dócil,

se soltara un tigre de duros y ágiles músculos

$y$ piel de nocturnos incendios, si se soltara

un saltamontes nevado, a saltar de verdad

sobre los montes lunares, no sería tan extraño el instante.

Traigo los dones y las maldiciones que

fueron acuñados para el hombre,

la memoria y sus hijos asombrosos, el tiempo y la muerte,

y los tres están llenos de criaturas que ya no abandonarán este suelo.

Durará en una huella sobre la piel ceniza del mundo blanco

el peso de los siglos, la reverberación de los rostros

de las entretejidas generaciones que me hicieron posible,

y acaso en la memoria de las estrellas

no se hablará de un hombre, se cantará que

un mundo mágicamente tocó las mejillas de otro

y volvió lleno de un impalpable horror,

de una maravilla imperceptible,

una sola certeza que se adicionó en oro

al caudal de su sangre y sus sueños.

\section{William Ospina}

Disponível em:

<https:// www.madrimasd.org/cienciaysociedad/poemas/poesia.asp?id=59> 